Tomas A. Lipinski and Andrea Copeland

\title{
Look before You License: The Use of Public Sharing Websites in Building Co-Created Community Repositories
}

\begin{abstract}
The legal aspects of building a co-created community repository (CCR) are explored through the examination of existing commercial web-based services. To determine whether commercial services offer a practicable option or a model for the creation of a CCR's terms of service (TOS), we analyzed six websites. The TOS contain the rules under which content can be stored, accessed, shared, etc. This TOS assessment is based on the consideration of four attributes, applied in a legal context: functionality, integrity, provenance, and permanence. While many of the features of a successful CCR are found across the services, none possesses all of the required elements. Recommendations for preferable CCR TOS are offered.
\end{abstract}

Tomas A. Lipinski, School of Library and Information Science, Kent State University, tlipins1@kent.edu

Andrea Copeland, School of Informatics and Computing, Indiana University-Purdue University Indianapolis, ajapzon@iupui.edu

\section{Introduction}

A vast array of information is shared and stored on social networking sites, blogs, and web pages, from text to images to recordings of music and spoken word to audio-visual works. A good portion of the content is self-produced, from fan-fiction stories to family photographs to garage-band covers of popular songs to clips of home-made "how-to" demonstrations. The sites, blogs, and pages posted by individuals are often made available through commercial providers. This content documents our collective social history and is primarily in the hands of corporate entities that could cease to exist tomorrow. For the most part, memory organizations are not involved in collecting and preserving the billions of words, images, sounds, and motion media created and stored digitally by millions of people who create this collective heritage. It has been asserted that there is a role for memory organizations to play in the curation of personal digital archives that will benefit individuals and society (Cox, Copeland).
Websites, like Facebook, that allow for the creation of personal and social archives have been accused of commercializing the public memory and the cultural record through the imposition of rules, i.e., the Terms of Service (TOS), and adoption of technologies that homogenize the experience of creating personal narratives (Garde-Hansen, Good). Others assert that there is much for cultural institutions to gain from understanding the practices of those who use corporate social network sites. Current practice can inform the curation endeavor by making institutional (memory organizations) collections useful, interesting, and used (Terras, Kennedy). The authors come from the perspective of individuals and cultural institutions working together in a social networking capacity to preserve public memory through the co-creation of personal and community repositories (Copeland and Barreau). Community members provide the content which documents local history, and the cultural institution provides the technical and legal knowledge and infrastructure for organization and preservation.

For libraries and other memory organizations to create a sustainable infrastructure for digital preservation they must collaborate with each other, create interoperable systems, and develop standards for creation, storage, and reuse (Bradley, Mason). For the collection and preservation of personal information of value to the social and cultural record by memory organizations, people need to be considered as part of the collaboration effort (Japzon). Unlike analog preservation, the best hope for digital preservation is to coordinate distribution, organization, and preservation of new content at the point of creation (Chen).

Recently, the Library of Congress archived over 170 billion tweets from the social media site Twitter but at this time they are not accessible for exploration or reuse. Their reason is that it is much easier to create and distribute information than it is to store and organize it for reuse.

This article discusses the legal considerations for the creation of repositories in memory organizations, specifically those hosted by public libraries and created in cooperation with their patrons. Co-created community repositories (CCRs) allow individuals to contribute to 
repositories digital objects of importance to them and the community. Think of a CCR as a "public Facebook" that is committed to collecting and preserving information which represents the individual in society, "where I becomes we" (McKemmish). CCRs could document and preserve the kinds of digital personal, family, local, and social histories currently being stored largely by commercial entities. The concept of CCR embodies a bottom-up rather than top-down model of knowledge creation and one that allows for knowledge sharing between the library and patrons, as well as between patron and patrons.

We analyzed the TOS of six commercial web-based services to determine whether such services are useful vehicles for the creation and housing of such repositories. Additionally, we examined the suitability of existing TOS as a potential model for public library repositories.

\section{Methods}

The focus of this investigation is not the technical or social aspects of a CCR, such as storage and retrieval issues, collection policies, or cost. Rather, the focus is whether the legal aspects surrounding use of these sites are compatible with the goals of CCR. The legal infrastructure or rules governing the use of these websites are found in the End User License Agreement (EULA), Terms of Service (TOS), or similar document. It is unclear whether there is a legal distinction between the two labels, but various websites use different labels. Facebook for example does not use either terms but calls its list of terms a "Statement of Rights and Responsibilities." Perhaps Terms of Service sounds less ominous or it may be that EULA is used where there is a clear "click-to-agree" mechanism on the website. EULA is used in the software-licensing context as well. Regardless, "TOS" will be used throughout this article to represent all documents of this nature.

Assessing whether any website would be a suitable vehicle for CCR depends upon the terms and conditions of use governing the service. Any use of existing web-based services by public library patrons would require patrons to agree to its TOS. To determine whether the TOS conforms to the legal characteristics required for CCR functionality, integrity, provenance, and permanence, this article reviews the agreements of the following services: Make History: National September 11 Memorial (sponsored by the 911 Memorial Museum), Creative Commons, Pinterest, Wikimedia, Yahoo!, Flickr, and Facebook. ${ }^{1}$

These six sites were selected for this evaluation to provide diverse examples of organizations that support online community created collections. The sites provide access mainly to images and image collections. Most important to this analysis, these sites have been generated in full or in part by individual users of the sites. Individuals contribute images and metadata and a corporate/organizational entity provides the technical and organizational infrastructure. The individual contributors, the public at large, and the corporate entity itself benefit from the collaboration. While Creative Commons is not a repository service, it supports the creation of content that is readily sharable in networked information environments. One might think of it as a distributed collection created by people who share a social information agenda.

We analyzed the terms of service for each of these websites vis-à-vis the relevant legal framework. Two questions guide the analysis: Are these websites potential storage and access locations for CCRs; and How can CCRs use these existing TOS as a model for TOS specific to CCRs?

\section{Terms of Services: Characteristics Considered for Analysis}

Without legally enforceable restrictions on the user to create, maintain, access, and share content in a CCR, a service that offered unlimited storage capacity would be as useless as one with quite limited storage capacity. Moreover, a website TOS can contain surprising or at times onerous and limiting provisions (in terms of functionality) that are likewise enforceable under the current contract law. These provisions can impede or limit use of the website for the purposes of a CCR. In light of this legal context, we identify several characteristics that an adequate CCR TOS should contain. We propose that the following minimum characteristics are required: Functionality, Integrity, Provenance, and Permanence (FIPP). An overview of these characteristics follows:

Functionality, a CCR's TOS provides

- The ability to create, store, access, and share a wide variety of user content in a variety of formats

- Restrictions on content and format restrictions or exclusions that are limited at most to unlawful

1 Full text of each website TOS, with commentary, provision by provision, is available from the authors upon request. 
content, unlawful in terms of the criminal law (child pornography, for example) or actionable in terms of the civil law (defamatory content, for example)

- Limited termination provisions, including adequate notice prior to termination

- Warranty (a legal promise), given by the provider, of service availability and functioning; and the potential for a warranty from users regarding the lawfulness of content.

Integrity (of legal particulars); a TOS requires an

- Opportunity to view terms coupled with a clear mechanism of assent to those terms (contract formation)

- Indemnification to accompany the service and user warranties provided

- Adequate notice of any change in terms

- Assent (agreement) to changes; this assent should be subject to a clear and distinct mechanism, e.g., a click-to-agree screen prompt.

Provenance (legal); the content of a TOS should include

- Copyright or other legal notices

- Attribution or other designations

- Identification of ownership rights for service provider and user

- Use rights to other licensees.

Permanence; a TOS should have in place

- Limitations on changes to service and content

- Limitations on removing the entire repository of a specific user, e.g., as a result of termination

- Articulation of whether content removal can occur in accordance with so-called take-down processes

- Processes for restoration of removed content in conjunction with the take-down process.

\section{Functionality}

To be useful to a CCR, the terms of service must provide the following aspects of functionality. The service must allow for the creation of patron content. In its simplest form the service must allow the user the ability to post content. Content can be textual, visual, oral, etc. This is an a priori element. This might be obvious. However, the six TOS agreements we examined restrict users from posting certain content. Therefore, restrictions imposed on the ability to post content must not be onerous. Minimalist restrictions would preclude the posting of unlawful content, for example. TOS agreements such as those examined here go beyond these limits in an attempt to establish standards of online comportment through a "code" of political correctness or civility and consider whether content is lawful. If such restrictions were imposed by an arm of the government, such as a state university or perhaps public library, the restrictions could face a legal challenge. See cases involving speech code on college campuses (DeJohn v. Temple University, Doe v. University of Michigan, Iota XI Chapter of Sigma Chi Fraternity v. George Mason University, McCauley v. University of Virgin Islands, UWM Post, Inc. v. Board of Regents of the University of Wisconsin System). Some may claim that there is merit in allowing some forms of unlawful (e.g. criminally obscene, actionable, or defamatory) content. This content too is part of the user story, in all its ugliness. Regarding content that raises the potential for civil liability, an online service provider like the six CCR hosts under discussion here is likely immune from all harms arising from content posted by users (47 U.S.C $§ 230$ ). Similar protection is also available to online service providers for claims of copyright infringement (17 U.S.C $\S 512$ ). A repository housed by a public institution would share in these immunities.

One advantage that an institution such as a public library may have, unavailable to a commercial entity, is immunity from prosecution under obscenity (Wisconsin Statutes § 944.21[8]) and harmful-to-minors (Wisconsin Statutes § 948.11[4]) statutes. Some states like Wisconsin offer immunity; other states like Illinois offer an affirmative defense (720 Illinois Compiled Statutes). Not every state offers such protection but a number do (Blum and Gerard and Bergthold). Once posted, the content must be available to the user. Whether the person who contributed the content desires continued access to it, or access by others is sought, a service should have rules (expressed in the TOS) that govern the cessation of access, i.e., suspension or termination.

A final legal concept is related to the quality of the service or its contents. In the world of contracts this concept can be embodied in the notion of warranty. In its simplest expression, a warranty is a legal promise. Warranties of concern here are the promises regarding whether or not the service will operate properly and promises made regarding the condition of the content, e.g., is the content error-free or is it lawful content, i.e., the content is not infringing on others' rights. Web-based services of all kinds often include such provisions in the governing TOS. While an operational warranty as to availability of service should be provided, it is unlikely for a provider to promise that the content will be provided error-free. A provider of content should provide not only a warrant (promise) that the content it provides to users is non-infringing, but it should offer an indemnification to go 
with it. Otherwise a licensee like a library should not enter into that agreement (Lipinski 2012, 463-66 and 496-98). Likewise, the service provider may require a promise that users are not posting content that is infringing.

\section{Integrity}

A second characteristic of a useful CCR is integrity. There are legal and practical aspects to integrity. The concept here does not refer to the integrity of the content (is it free from error). Here legal integrity relates to contract formation or assent issues, to the soundness of the bargain, so to speak. The TOS should be available for review prior to use of the service and there should be a clear indication of how a user assents or agrees to be bound by the provisions of the TOS. A user should be aware of the mechanism by which he or she enters into the agreement. Many websites use a "click-to-agree" mechanism. If changes are made to the TOS, how are the changes communicated, then agreed upon? In other words, what constitutes assent on the part of a user to be bound by the terms extant at first use as well as to changes made thereafter, i.e., what constitutes assent to changes in the terms? To a reader ignorant of the world of licensing, this might appear obvious-that the rules of use should not change midstream. However, a number of licenses including the TOS agreements reviewed here contain provisions that allow for change in the terms at any time and for any reason.

Licenses, like other legal documents, can evolve over time, or a change in the law might necessitate a change in terms. While this is acceptable, what is more important is whether changes are communicated to the user and whether the user, upon a change to less favorable terms, has the ability to terminate the license. iTunes reflects a common approach. In one provision entitled "CHANGES" is the following: "Apple reserves the right at any time to modify this Agreement and to impose new or additional terms or conditions on your use of the iTunes Service. Such modifications and additional terms and conditions will be effective immediately and incorporated into this Agreement. Your continued use of the iTunes Service will be deemed acceptance thereof" (Apple). In three short sentences, Apple indicates that it can change the rules governing the use of music acquired through its service; it is not going to tell a user when the changes occur and that if a user continues to use the iTunes Service, that use constitutes agreement to the new terms.

Users need to be aware of the consequences of interaction in social networking and environments in which terms can change without notice and in which use equates agreement to those changes. There is some question as to whether or not such "check our website" messages are valid mechanisms of notice. Since the social network TOS agreements reviewed are a form of massmarket non-negotiated agreements, then at least in the United States Court of Appeals for the Ninth Circuit such changes might not be valid. According to decisions such as Douglas v. Talk America, Inc., such a clause would not be enforceable (Douglas v. Talk America, Inc., 495 F.3d 1062). "Talk America posted the revised contract on its website but, according to Douglas, it never notified him that the contract had changed. Unaware of the new terms, Douglas continued using Talk America's services for four years" (Douglas v. Talk America, Inc., 495 F.3d 1062, 1065). The court concluded that the new terms were not part of the agreement: "Even if Douglas had visited the website, he would have had no reason to look at the contract posted there. Parties to a contract have no obligation to check the terms on a periodic basis to learn whether they have been changed by the other side" (Douglas $v$. Talk America, Inc., 495 F.3d 1062, 1065). A proposed new term once the contract is formed represents an offer for additional terms that in theory requires assent. This is a non-negotiated agreement and is suspect in terms of enforceability: "Nor would a party know when to check the website for possible changes to the contract terms without being notified that the contract has been changed and how. Douglas would have had to check the contract every day for possible changes. Without notice, an examination would be fairly cumbersome, as Douglas would have had to compare every word of the posted contract with his existing contract in order to detect whether it had changed" (Douglas v. Talk America, Inc., 495 F.3d 1062, 1066). Even the iCloud adopts a use-equal-assent approach for changes in TOS; the agreements examined raise contract formation and assent issues. Each of the services examined exhibits some form of use-equalsagreement in either or both contract-formation and change-of terms-provisions.

The federal government has moved forward in an attempt to alert users about a think-before-you-click strategy, providing guidance on TOS agreement elements and a list of "approved" social media websites and services. Two of the services reviewed here, Facebook and Pinterest, are on that list as well as others familiar to most readers such as Instagram, MySpace, and Twitter (HowTo. gov). The two major concerns expressed by the Office of Legal Counsel, U.S. Department of Justice involved two of the many issues discussed in this paper: indemnification provisions and authority. 
In specific, broad "open-ended" indemnification clauses that pose "potentially unrestricted liability" (Whitehouse.gov) violate the Anti-Deficiency Act (codified at 31 U.S.C. $\S 1341$ ) which prohibits employees from obligating the federal government to financial commitments before obtaining proper "appropriation" (31. U.S.C. § 1341[a][1]). An employee may not have the proper authorization to bind the federal government. Adequate consent was also discussed, with the Office of Legal Counsel concluding that resolution of the issue depends upon the extent to which the user had "reasonable notice of and manifested assent to the online agreement" (Whitehouse. gov).

The second aspect of legal integrity is whether the service, upon providing warranty as to the content available (see above, under functionality), also provides an indemnification, which is the "action of compensating for loss or damage sustained" (Black's Law). In the contractual context under discussion, an indemnification regarding the content operates to "make good," in a sense, a broken promise, i.e., a failed warranty. If there is a promise or warrant by the service provider that the content provided is not infringing under the copyright law, and should it turn out that the content is indeed infringing, then under the rules of liability in copyright use of the infringing content by a website, a user might likewise be infringing. This is why a licensee of a database of articles desires to have the vendor warrant that the content is non-infringing and indemnify the licensee in case it turns out the vendor was wrong and the content supplied turns out to be infringing. The indemnification provides that should the licensee be sued for copyright infringement, the content provider will not only provide for the legal defense of the licensee in the litigation, but also be responsible for any damages owed by the licensee to the copyright owner. It is typical also to have the warranty and indemnification survive the duration of the contract or TOS. It is not uncommon for services that allow a user to post or otherwise submit content to require that the user indemnify the service provider. In contract law such indemnifications should not be entered into lightly, as the party offering the indemnification in a sense promises to underwrite the malfeasance he or she may cause. An indemnification thereby provides a form of self-insurance on the part of one party to another.

\section{Provenance}

A third characteristic of a CCR is provenance, but provenance again in a legal sense. What identifying information must accompany use of the content? This could include a copyright notice, or, if the work is derivative, mention of the source work. There may also be other rights of attribution and presentation known as moral rights, that are a slightly different legal creature than copyright and are more developed in the legal traditions of European countries than they are in the United States. They have limited application in U.S. law (17 U.S.C \& 106A). Droit moral, or moral right, is generally defined as including "the right of an artist to have his work attributed to him in the form in which he created it to prevent mutilation or deformation of the work" (Museum Boutique Intercontinental, Ltd. v. Picasso).

The United States offers visual artists limited rights (17 U.S.C. § 106A). In Europe the legal protection visà-vis moral rights is more extensive. In the context of cross-border and multi-jurisdictional locales, "digital technology makes the enforcement of moral rights on an international scale a very complicated task" (Fang). Consistent legal approaches across the globe depend on harmonization of moral rights legislation. This is unlikely as commentators in the European Union begin calling for increased protection: "there is an even greater urgency to adopt the EC Directive over moral rights due to the rapid growth of the Internet. A higher number of moral rights violations occur because this new form of technology makes it easier to modify works" (Sirvinskaite).

A second aspect of provenance relates to the ownership of the content made available to users or able to be posted by users. The most relevant legal ownership right is copyright. The TOS should not take away the ownership rights of users in their content. Regardless of ownership retention by a user, a critical aspect of a CCR is access and use by other contributors and users. The repository service provider must be able to make submitted content available to the other users. Other users must be able to make use of content posted and owned by another user; a user must be required to grant these use rights to others. When this right of use is granted, by the copyright owner, to the service or to other users through a license, the phrase "non-exclusive rights" is used. This indicates that the user retains copyright ownership, as only nonexclusive rights are offered through the TOS from the user-owner. Likewise, the availability of the content to other users does not mean that the other users acquire 
ownership when they access the content, as they have only non-exclusive rights, and share these use rights with other users. It is possible for the use rights provision to prohibit derivative or commercial uses. This is essential if a person is to access and use the contributions made by other users, as the CCR is a community-based asset.

\section{Permanence}

A final characteristic of a CCR is permanence. If the content submitted is ephemeral and does not have some permanence it will not be useful as a patron or community record. There are two aspects to permanence: change in content and outright removal of content. As a subset of the removal aspect, does the provider in specific follow the take-down rules of the federal copyright law, i.e., the removal is made to the take-down provisions of 17 U.S.C. $\$ 512$ (c)? If this process occurs, is the restoration mechanism of the same provision, subsection ( $\mathrm{g}$ ), also available? If the service can make changes in the content, is notice of the change provided to users? While the ability of the service provider to make changes is not desirable, at least with notice the user who submitted the content would be alerted and could seek an alternative location to where the content could be migrated, reside, and be accessible in the future. A website might also be a section 512 service provider having registered as such with the U.S. Copyright Office (U.S. Copyright Office).

The obligations under section 512 are not required of every service provider, only those who wish to participate as a registered service provider; but if the provider does not follow the section 512 process, there is no clear protection from damages either. For a thorough discussion of section 512 see Lipinski 2006, 141-230. With regard to section 512, a service provider has an obligation to expeditiously remove or disable access to content when it receives a notice claiming the content is infringing. The notice process is articulated in statute. The same removal or disabling is required if a service provider possesses actual knowledge of its infringing nature or "in the absence of such actual knowledge, is unaware of facts or circumstances from which infringing activity is apparent" (17 U.S.C. $§ 512[c][1][A][i i])$. While there is a mechanism that allows restoration of removed or blocked content, some service providers may not be aggressive in helping their users pursue this option.

\section{Terms of Service Considerations for CCR Functionality}

\subsection{Contributing Content}

The Terms of Use of the "Make History: National September 11 Memorial" (website) indicates that users may add content to document experiences of users "both at the attack sites and around the world." While not explicit, it is implied that users can post their content, recollections, tributes, etc. of their experiences of 9-11. Creative Commons does not have provision for this either, but that is understandable as it is a license service, i.e., it provides a licensing scheme that those supplying content to others can use. Likewise, Yahoo! being a hosting service does not include specific reference to user-created content. In contrast, Pinterest makes it clear that the service "allows" users "to create online pinboards and organize and share beautiful things you find on the web ... create your own visual collections." Pinterest also lets users "view and follow other" posts of fellow users. Paragraph 1 "allows you to pin and post content on the Service, including photos, comments, and other materials." Wikimedia likewise encourages the submission of content. Its "mission is to empower and engage people around the world to collect and develop content under a free license or in the public domain, and to disseminate it effectively and globally, free of charge." Content "is contributed and made possible by users." It would appear obvious that a Facebook user can post content to his or her page but the TOS agreement does not mention this specifically; it does indicate, however, that "removed content may persist in backup copies for a reasonable period of time" (website).

\subsection{Portability}

The issue of portability is not mentioned in Pinterest. There is nothing prohibiting a user from doing this but there is no indication that Pinterest would assist in the process. Wikimedia is similarly silent, but as with Pinterest it has broad discretion to keep content, yet little responsibility to warrant (promise) that it will remain available or not be deleted, corrupted, etc. Yahoo! says that it "will allow you and the people with whom you communicate to save your conversations in your Yahoo! accounts located on Yahoo! servers. This means you can access and search your message history from any computer with access to the 
internet. . . . Your agreement to this TOS constitutes your consent to allow Yahoo! to store these communications on its servers." So while such history is available, there is no promise of assistance. Facebook is likewise silent. This is in contrast to various cloud computing TOS agreements which go a step farther. The Dropbox TOS agreement offers the following: "If we suspend or terminate your use, we will try to let you know in advance and help you retrieve data." The iCloud TOS indicates that in response to a change in terms if users "do not agree with them, you must stop using the service and contact icloud Support to retrieve your Content." One would expect users to have better support regarding the ability to retrieve content for various purposes including portability (Lipinski, 2013).

\subsection{Content Restrictions}

The "Make History: National September 11 Memorial" website prohibits the contribution of an array of content that is in some way unlawful or tied to unlawful activity: "illegal, defamatory, threatening, obscene, scandalous, instigating, pornographic, profane materials or any other kind of material that can be labeled as an offense against persons or organizations involving civil or criminal liability." Again, as it is a licensing service, the Creative Commons does not prohibit any content per se. Pinterest prohibits the use of "user names or board titles that are offensive, obscene, or harassing to others." It also can require a user to change his or her "user name or the title of your board." Enforcement of such a provision might result when a contributor's user name or board title reads "pinterestsucks" or "pinterestreallybites" for example. There are documented instances of disgruntled users of various products and services from Verizon Wireless (verizonsucks.com, verizonreallysucks.com, and 'VerizonShouldSpendMoreTimeFixingItsNetworkAndLessMoneyOnLawyers.com) (Headley) to Guinness beer (Guinness-Sucks.com, Guinness-Beer-Sucks.com, Guinness-Beer-Really-Sucks.com, and Guinness-BeerReally-Really-Sucks.com) (Biederman) and domain names for example.

A similar prohibition against unlawful or potentially unlawful activity is found in the Wikimedia Terms of Service. It warns against: "Harassing and abusing others ... violating the privacy of others . . . engaging in false statements, impersonation, or fraud . . . committing infringement . . . misusing our services for other illegal purposes . . . engaging in disruptive and illegal misuse of facilities." Yahoo! contains a lengthy list of unwelcome content: "unlawful, harmful, threatening, abusive, harassing, tortuous, defamatory, vulgar, obscene, libelous, invasive of another's privacy, hateful, or racially, ethnically or otherwise objectionable" as well as content that might breach a legal duty such as a gag order imposed during court proceedings ("Content that you do not have a right to make available under any law") or that which is prohibited by a contractual or fiduciary duty, that would violate the intellectual property laws, any advertising such as spam or other solicitation, and any virus or code of a similar nature.

Facebook terms of service contain a similar prohibition on commercial content as well as "hate speech, threatening, or pornographic; incites violence; or contains nudity or graphic or gratuitous violence," and a sweeping general statement excluding content or action which "infringes or violates someone else's rights or otherwise violates the law." While some prohibited speech is beyond First Amendment protection and proscribable, such as incitement or child pornography, other speech remains so protected and is not proscribable unless it is tied to intimidating conduct, as observed by the Supreme Court which observed: "We conclude that while a State, consistent with the First Amendment, may ban cross burning carried out with the intent to intimidate, the provision in the Virginia statute treating any cross burning as prima facie evidence of intent to intimidate renders the statute unconstitutional in its current form" (Virginia v. Black). Intimidation as an element of the crime must be determined apart from the statute but from extrinsic evidence from the circumstances of the act, i.e., the cross burning. Regardless of the intrinsic legality of such prohibitions, once the user agrees to the restrictions, the user is bound to abide by their contractually imposed "gag-order." Provisions like these demonstrate the power of TOS in restricting speech. Many of the examples recounted here reach lawful content. Furthermore, terms such as "otherwise objectionable" are void of legal and contractual meaning. It should be noted however that a TOS agreement cannot make an unlawful act lawful. A provision could not allow users the right to post child pornography.

While there have been "sharp increases in hate sites and complaints of Internet hate and abuse, an examination aimed at preventing resultant and future harms ... must surpass the Supreme Court's longstanding First Amendment's protections. Since the Supreme Court has not addressed Internet hate speech, this examination must appeal to the general First Amendment jurisprudence from want of specific guidance" (Baumrin). As such, Internet hate speech (as is hate speech in general) is protected speech unless it incites or meets narrow Supreme Court 
standards. A state for example "may ban cross burning carried out with the intent to intimidate" if the element of intent is proved as a separate element (Virginia v. Black).

\subsection{Disclaimers of Warranty}

While it is preferable for TOS agreements to warrant (promise) that the service be available, licensors often disclaim warranties, negating the reasonable expectations of the user that the service will be available and will work properly. All of the agreements reviewed contained a disclaimer of warranty regarding either its service, the content posted, or both. In contract law there is a requirement that language waiving certain responsibilities by a licensor be conspicuous, thus it is often found in capital letters. A common warranty disclaimer takes the form of an "as is" provision. An "as is" warranty generally means that the item is sold in its present condition and that it may contain faults. Many states require such waivers to be conspicuous, for example, printed in all capital letters.

The Make History: National September 11 Memorial site is provided "as is" without express or implied warranties. It does not warrant or promise that the content is "accurate, reliable or correct, that this site will be available at any particular time or location, or that the site is free of viruses or other harmful components." Creative Commons desires to make sure that users know its disclaimers, so it includes such up front in its preamble and again in a substantive provision regarding the information. Paragraph 5 contains the substantive provisions, repeating the "as is" phrasing as well as making "no representations or warranties of any kind ... including, the absence of latent or other defects, accuracy, or the presence or absence of errors, whether or not discoverable" (website). Likewise, Pinterest in Paragraph 9 of its TOS provides content "as is" and "as available." Pinterest specifically disclaims "warranties and conditions of merchantability, fitness for a particular purpose, quiet enjoyment and non-infringement" (website).

Implied warranties are a subspecies of warranty that developed over time. General notions of fair dealing imply that contracts for goods and services contain warranties of satisfactory quality and accuracy or fitness for a particular purpose. An "implied warranty of fitness for a particular purpose" is a warranty [that is] implied by law if the seller has reason to know of the buyer's special purposes for the property-that the property is suitable for those purposes" (Black's Law). A more general warranty that the product is fit to be sold is known as an implied warranty of merchantability, i.e., a "warranty that the property is fit for the ordinary purposes for which it is used" (Black's Law).

Wikimedia uses the familiar "as is" and "as available" but also adds that it does "not represent or guarantee the truthfulness, accuracy, or reliability of any submitted community content" or that it is "timely" or "error-free." Likewise, it disclaims implied and express warranties and, in specific, the implied warranties of merchantability, fitness for a particular purpose, and non-infringement. For public domain content that is submitted, users are required to warrant "that the material is actually in the public domain, and you agree to label it appropriately." Yahoo! also provides its service "as is" and "as available." It will not be "liable" for content including "any errors or omissions."

Oddly, Yahoo! is one of two services examined here that require a user to indemnify it from claims of other users or third parties due to content submitted, posted, transmitted, modified or otherwise made available by that user through its service. It also disclaims implied and express warranties and in specific the implied warranties of merchantability, fitness for a particular purpose, and non-infringement. Facebook does not have an "as is" provision but does disclaim implied and express warranties and in specific the implied warranties of merchantability, fitness for a particular purpose, and non-infringement. Paragraph 3 also states that there is no guarantee that Facebook will be error free. Facebook also contains a requirement that users indemnify it and hold it "harmless from and against all damages, losses, and expenses of any kind (including reasonable legal fees and costs) related to such claim" (website). In other words, the message of such services is clear. Do not rely upon or base significant decisions on the content you find in our service. Proceed with caution, buyer beware, etc. To an extent, this is logical, as users are responsible for creating the content and the provider cannot insure that users are posting error-free content. The service provider is not an editor; it is not acting in the role of a traditional publisher. A public library or other institution in similar stead would likely make the same disclaimer.

\subsection{Termination Policies}

Most services reserve the right to terminate users. Rather than recommending against any termination right whatsoever, the more significant concerns are whether the termination is for a legitimate reason, and if for a legitimate reason, whether notice is provided offering an opportunity for corrective action so the termination does not 
Fig. 1: Functionality Provisions in Public Sharing Website TOS, Examples.

\begin{tabular}{|c|c|c|c|c|}
\hline & $\begin{array}{l}\text { Ability to contribute content: } \\
\text { create personal repository }\end{array}$ & $\begin{array}{l}\text { Content prohibited } \\
\text { (bold/italics entries: lawful } \\
\text { content and may pose prob- } \\
\text { lems of legal definition) }\end{array}$ & $\begin{array}{l}\text { "As is" and other warranty } \\
\text { disclaimers relating to } \\
\text { accuracy or availability of } \\
\text { service, including damages. }\end{array}$ & $\begin{array}{l}\text { Termination: the loss of the } \\
\text { ability to contribute content }\end{array}$ \\
\hline $\begin{array}{l}\text { Make History: } \\
\text { National } \\
\text { September } 11 \\
\text { Memorial }\end{array}$ & $\begin{array}{l}\text { No specific language in the } \\
\text { Terms of Service but website } \\
\text { indicates purpose is to allow } \\
\text { users to document their } \\
\text { experiences of September } \\
11 .\end{array}$ & $\begin{array}{l}\text { Prohibits posting of "illegal, } \\
\text { defamatory, threatening, } \\
\text { obscene, scandalous, } \\
\text { instigating, pornographic, } \\
\text { profane materials" or that } \\
\text { would otherwise incur "civil } \\
\text { or criminal liability." }\end{array}$ & $\begin{array}{l}\text { "As is" and "as available." } \\
\text { Express and implied warran- } \\
\text { ties disclaimed. No warrant } \\
\text { of the accuracy, reliability, or } \\
\text { correctness of content or that } \\
\text { the site is free from viruses. }\end{array}$ & $\begin{array}{l}\text { Right to terminate at any } \\
\text { time for any reason. }\end{array}$ \\
\hline $\begin{array}{l}\text { Creative } \\
\text { Commons }\end{array}$ & Not applicable. & Not applicable. & $\begin{array}{l}\text { "As-is," no warranty } \\
\text { regarding the information. } \\
\text { Damages are also dis- } \\
\text { claimed, representations } \\
\text { or warranties including the } \\
\text { absence of defects or errors } \\
\text { or accuracy of the work. }\end{array}$ & $\begin{array}{l}\text { Automatic termination upon } \\
\text { breach of terms. }\end{array}$ \\
\hline Pinterest & $\begin{array}{l}\text { Allows users to "pin and post } \\
\ldots \text { photos, comments, and } \\
\text { other materials" and to view } \\
\text { the posts and pins of others. }\end{array}$ & $\begin{array}{l}\text { Prohibits posting "user } \\
\text { names or board titles that } \\
\text { are offensive, obscene, or } \\
\text { harassing to others." Pinter- } \\
\text { est can change a user name } \\
\text { or the board title as well. }\end{array}$ & $\begin{array}{l}\text { "As is" and "as available." } \\
\text { Express and implied war- } \\
\text { ranties disclaimed. Specific } \\
\text { warranties of merchantabil- } \\
\text { ity, fitness for a particular } \\
\text { purpose, quiet enjoyment } \\
\text { and non-infringement, and } \\
\text { any warranties arising out of } \\
\text { dealing or usage of trade are } \\
\text { disclaimed. }\end{array}$ & $\begin{array}{l}\text { Right to terminate at any } \\
\text { time for any reason or } \\
\text { for no reason. Temporary } \\
\text { suspension or termination } \\
\text { for breach of terms or for no } \\
\text { reason. }\end{array}$ \\
\hline Wikimedia & $\begin{array}{l}\text { The service "host[s] an } \\
\text { incredible quantity of edu- } \\
\text { cational and informational } \\
\text { content" that is "contributed } \\
\text {... by users" and encour- } \\
\text { ages others to "collect and } \\
\text { develop content." }\end{array}$ & $\begin{array}{l}\text { Prohibits the following } \\
\text { content: } \\
\text { harassing and abusing } \\
\text { others, "violating the privacy } \\
\text { of others, } \\
\text { engaging in false state- } \\
\text { ments, impersonation, or } \\
\text { fraud, committing infringe- } \\
\text { ment, misusing our services } \\
\text { for other illegal purposes, } \\
\text { engaging in disruptive and } \\
\text { illegal misuse of facilities." }\end{array}$ & $\begin{array}{l}\text { "As is" and "as available." } \\
\text { Express and implied war- } \\
\text { ranties disclaimed. Specific } \\
\text { warranties of merchantabil- } \\
\text { ity, fitness for a particular } \\
\text { purpose, quiet enjoyment, } \\
\text { and non-infringement dis- } \\
\text { claimed. No representation } \\
\text { of "truthfulness, accuracy, or } \\
\text { reliability" of content or that } \\
\text { it is "error free." } \\
\text { Users must warrant that } \\
\text { public domain content is } \\
\text { indeed in the public domain } \\
\text { and label it so. }\end{array}$ & $\begin{array}{l}\text { Right to suspend or termi- } \\
\text { nate at any time, with or } \\
\text { without cause, and with or } \\
\text { without notice. Contributed } \\
\text { content will remain publicly } \\
\text { available. }\end{array}$ \\
\hline
\end{tabular}




\begin{tabular}{|c|c|c|c|c|}
\hline & $\begin{array}{l}\text { Ability to contribute content: } \\
\text { create personal repository }\end{array}$ & $\begin{array}{l}\text { Content prohibited } \\
\text { (bold/italics entries: lawful } \\
\text { content and may pose prob- } \\
\text { lems of legal definition) }\end{array}$ & $\begin{array}{l}\text { "As is" and other warranty } \\
\text { disclaimers relating to } \\
\text { accuracy or availability of } \\
\text { service, including damages. }\end{array}$ & $\begin{array}{l}\text { Termination: the loss of the } \\
\text { ability to contribute content }\end{array}$ \\
\hline Yahoo! & None. & $\begin{array}{l}\text { Prohibits } \\
\text { unlawful, harmful, threaten- } \\
\text { ing, abusive, harassing, } \\
\text { tortuous, defamatory, vulgar, } \\
\text { obscene, libelous, invasive } \\
\text { of another's privacy, hateful, } \\
\text { or racially, ethnically or } \\
\text { otherwise objectionable, } \\
\text { content that by contract, } \\
\text { fiduciary duty, or other law } \\
\text { is not able to be posted, } \\
\text { content that would violate an } \\
\text { intellectual property right, a } \\
\text { broad array of solicitations, } \\
\text { virus or similar harmful code. }\end{array}$ & $\begin{array}{l}\text { "As is" and "As available." } \\
\text { Express and implied war- } \\
\text { ranties disclaimed. Specific } \\
\text { warranties of merchantabil- } \\
\text { ity, fitness for a particular } \\
\text { purpose, quiet enjoyment } \\
\text { and non-infringement. } \\
\text { Paragraph } 11 \text { requires that } \\
\text { a user indemnify Yahoo! } \\
\text { from claims of others due to } \\
\text { content of another user. }\end{array}$ & $\begin{array}{l}\text { Right to terminate or } \\
\text { suspend without notice. } \\
\text { Right to suspend or termi- } \\
\text { nate if user supplies untrue, } \\
\text { inaccurate, not current, or } \\
\text { incomplete registration infor- } \\
\text { mation or Yahoo! reasonably } \\
\text { suspects such information is } \\
\text { supplied. }\end{array}$ \\
\hline Facebook & $\begin{array}{l}\text { No specific mention but } \\
\text { there is an assumption } \\
\text { that content can be posted } \\
\text { as "removed content may } \\
\text { persist in backup copies for a } \\
\text { reasonable period of time." }\end{array}$ & $\begin{array}{l}\text { Prohibits "unauthorized } \\
\text { commercial communications } \\
\text { (such as spam)" as well as } \\
\text { "hate speech, threatening, } \\
\text { or pornographic; incites } \\
\text { violence; or contains nudity } \\
\text { or graphic or gratuitous } \\
\text { violence" and content } \\
\text { that "infringes or violates } \\
\text { someone else's rights or } \\
\text { otherwise violates the law." }\end{array}$ & $\begin{array}{l}\text { No specific "as is" disclaimer } \\
\text { but express and implied war- } \\
\text { ranties disclaimed. Specific } \\
\text { warranties of merchantabil- } \\
\text { ity, fitness for a particular } \\
\text { purpose, quiet enjoyment, } \\
\text { and non-infringement. No } \\
\text { promise that the service is } \\
\text { error free. }\end{array}$ & $\begin{array}{l}\text { Termination upon breach of } \\
\text { the terms ("the letter") as } \\
\text { well as the spirit of the terms } \\
\text { or when legal harm is per- } \\
\text { ceived. Notice provided via } \\
\text { email or upon next log-in. }\end{array}$ \\
\hline
\end{tabular}

occur. This is known in contract parlance as a "cure right" or "right to cure." Suspension is a related concept but often occurs without notice; right to cure is not applicable in this case. It is a dangerous provision from the user perspective, as the trigger is often the subjective opinion of the provider-licensor and should be avoided where possible.

The "Make History: National September 11 Memorial" can terminate users "at any time at its sole discretion." Creative Commons can terminate users upon breach of the terms. Note that the breach right applies to immaterial (as opposed to material) breaches of the terms of service. It is more typical in contract to predicate a right to terminate on the breach of a material term by the other party that has not been cured. It is also typical to give the party in breach some time during which the material breach can be fixed or "cured"; and if the cure is successful, the party can avoid termination. In the case of work distributed subject to a CC license, if the user breaches any term then any permission granted by the license to a particular user ends, as does the license with that user. The Creative Commons governing the same with other users remains in place and in force, unless of course they also breach any of the terms. Pinterest can also terminate users "at any time for any reason or no reason." If the terms are breached, then services can be temporarily suspended or terminated, and "for no reason" whatsoever. Wikimedia reserves "the right to suspend or end the services at any time, with or without cause, and with or without notice." Although it does assure users that, upon termination, content will remain available: "your public contributions will remain publicly available." Yahoo! can terminate or suspend an account if a user provides or is suspected of providing information that is untrue, inaccurate, not current or incomplete" or it can without notice and apparently without reason "immediately terminate, limit your access to or suspend" access to it. Under paragraph 14 Yahoo! can cease to provide its service, a sort of termination en masse. Facebook can terminate users for breach of terms or when it believes the spirit of the terms is violated, however that might be determined. It can also 
terminate users if it believes conduct is creating "risk of legal exposure." Notice is provided of the termination via email or upon the next access of a user's account (Fig. 1).

\subsection{Functionality Considerations for CCRs}

Ignoring those websites that provide service aloneCreative Commons and Yahoo!--the remaining websites, while allowing users to post content, nonetheless raise significant functionality issues. It is understandable that a repository purveyor does not want to house unlawful content. On the other hand, there can still be value in such content precisely because of its unlawful status. Public and academic libraries in the United States may contain publications that have been found to be unlawful at some point in time, due to content deemed defamatory or obscene. Moreover, the prohibitions listed also prohibit lawful content such as hate speech and nudity. The lack of warranty regarding such information is also understandable but can make the content less useful to some users. While a CCR host site might not make the promise that all content is $100 \%$ accurate or free from all error, it might be more significant for a CCR to warrant to other users that submitted content has not been altered from its original post. This insures that the content contributed by a user has not been tampered with other than minor editing by the contributing user; it appears just as originally intended. Users might be able to append their contribution but are prevented from re-writing their own history, unless there is a mechanism to record or otherwise trace changes.

The fear expressed in a TOS agreement regarding unlawful content is a red herring. Other than that which violates criminal law or infringes on intellectual property right, federal law protects an interactive computer service from the online postings made by third parties when that post is intended for distribution or access on the Internet (47 U.S.C. § 230). The definition of "interactive computer service" in subsection (f)(2) is broad enough to include libraries: "The term 'interactive computer service' means any information service, system, or access software provider that provides or enables computer access by multiple users to a computer server, including specifically a service or system that provides access to the Internet and such systems operated or services offered by libraries or educational institutions" (47 U.S.C. § 230[f][2]). It is clear from the statute that immunity would be extended to a public library that housed a CCR. Therefore, for commercial and public institutional online repositories, it could be claimed that such restrictions are unnecessary. However, there may be other drivers motivating restrictions on content. The Make History: National September 11 Memorial website offers an example, restricting content to that which is related to the events and experiences of 9-11. For example, a public library hosting a CCR may want to restrict content to representations, histories, and experiences of life in the community that the library serves. The concern is not whether the content is tortuous, objectionable, etc. but whether it meets the requirements of the particular CCR goal of building a local public history repository. Similar to the Make History: National September 11 Memorial website, a public library may want to provide a similar space for patrons to post the experiences of a local disaster, such as a tornado or flood. This is a collection decision based on the limits of the public forum the library desires to create. In terms of First Amendment analysis, such a repository allowing patron contribution would be a "limited public forum" as the term is understood by the courts (U.S. v. Kolinda). "If a designated public forum is limited to certain kinds of speakers or to the discussion of certain subjects it is sometimes called a limited public forum" (Pfeifer $v$. City of West Alllis). A library might desire that only patrons from its service area be allowed to contribute.

A CCR might also want to disclaim legal responsibility for service or content errors. It is anticipated that a less restrictive CCR TOS agreement might generate discussion or even dispute over content propriety, similar to that involving filters and Internet access. If a library is to have a more liberal content provision, it could create a search system that would allow a particular user to tailor retrieval of content in light of sensitivities or preferences and exclude such content from the search results. There are many criteria that could be enforced but not because another user might find the content objectionable in some way.

Finally, the TOS agreements reviewed here provide liberal termination rights to the website purveyors, often for no cause, or with cause (for breach) without a right to cure provision. It is typical for a cure right to exist where one party is in breach, but before termination of service can occur, the non-breaching party is obligated to give the other party notice of breach and a period of time within which he or she can cure the breach without negative repercussions. If a public library believes it necessary to preserve the termination right, then to encourage community participation in a CCR it may want to consider including a suspension provision that, short of termination, offers a graduated system of penalties similar to policies relating to patron access to facilities and including notice and cure within its termination provision. A CCR suspension policy would parallel public library policies 
now in place that govern the physical space of the library, such as those regarding disruptive patrons. Suspension policies comply with constitutional sensitivities regarding the liberty interest that courts have concluded public library patrons possess. As one court expressed it: "this court finds that Wayfield [the excluded patron] states a sufficient claim to support a finding that the suspension of his access to the library was a deprivation of a 'liberty or property right.' The court must next determine whether Wayfield was afforded pre- or postdeprivation due process sufficient to satisfy the mandate of the Fourteenth Amendment" (Wayfield v. Town of Tisbury). In a public library setting, this liberty interest indicates that, before such liberty can be denied, and the patron banned from the library or in this case access to the CCR, any denial of access (a suspension) should be for limited times, e.g., the rest of the day, be graduated in its imposition (one full day, one week, etc.), or where a longer period is contemplated (one month, 6 months, one year, etc.). The patron should be offered notice and a right to be heard before the suspension is imposed.

\section{Integrity}

\subsection{Assent Issues}

The legal integrity of the contract is necessary for the ordering of many relationships in our society. If a party cannot be held to its promises and obligations under a contract, then the other party will seek to enforce those promises and obligations as it sees fit, with each party becoming an enforcement vigilante. Such an environment promotes inefficiency and distrust of bargain-making. A climate in which contracts can be relied upon is efficient, as opposed to a climate in which doubt and second-guessing prevail. A legal relationship built upon law promotes consistency in interpretation.

Central to this concept of efficiency and consistency is the availability of terms and a clear mechanism of acceptance of those terms. Proper contract formation requires an opportunity to read the TOS agreements prior to the moment of contract formation. Legally this is not always the case. So called "pay now-terms later" agreements, also known as rolling contracts, are enforceable (ProCD, Inc. v. Zeidenberg), but a CCR contract should be transparent and allow all parties ample opportunity to review the terms prior to the moment of agreement (contract formation). There should also be a clear mechanism, of assent or agreement to the TOS. In online settings this is often accomplished by use of a click-to-agree mechanism whereby the website visitor clicks "I accept" or some similar icon. Here, a specific act, a "click," indicates assent. In contrast, the Make History: National September 11 Memorial, Creative Commons, Pinterest, Yahoo! and Facebook all make clear that mere use equals assent to the TOS. Assent is not indicated by a separate process, as in a click-to-agree scenario. A similar result is implied by the Wikimedia TOS ("if you do not agree with our Terms of Use, you cannot use our services"). What is problematic about such use-equals-assent contracting is, how does one distinguish between use-equals-assent and usejust-equals-use? It is dangerous to equate assent with an expected course of action of the product or service.

\subsection{Changes in Terms}

A second aspect of legal integrity is the circumstances under which changes to the TOS can be made. Make History: National September 11 Memorial can update its terms at its "sole discretion" and without any mechanism of notice to the user. Likewise the Yahoo! "guidelines or rules" may also be modified "from time to time." There is no mechanism of notice to users. Worse, in a use-equalsassent setting, use of the website after a change is posted results in a situation in which the user is deemed to having accepted the changes. How will a user distinguish between assent and plain old use alone? The user cannot make this distinction, and that is the point from the service provider's perspective; it makes it easier to change terms that then become part of the agreement every time the user logs on. The sole alternative is not to log into the service until the TOS have been reviewed for changes; if the user does not agree, then he or she must stop using the service.

\subsection{Notice of Changes}

A significant question in this setting is whether or not the user receives a prompt that the terms have changed. It is preferable that parties receive notice of changes in material terms-those terms that go to the heart of the bargain-with an opportunity to terminate if the terms are unacceptable. "Although the phrase 'material' is subject to interpretation, it has been defined as 'affect[ing] the purpose of a contract in an important or vital way" (Classen). Price would be a material term (Danne). Effective notice includes not just that the terms have changed ("so please check our website for an updated 
Fig. 2: Integrity of the Legal and Practical Circumstances of Public Sharing Website TOS, Examples.

\begin{tabular}{|c|c|c|c|c|}
\hline & $\begin{array}{l}\text { Contract Formation: Assent } \\
\text { Issues }\end{array}$ & Change in terms & Notice of Changes in Terms & Indemnification \\
\hline $\begin{array}{l}\text { Make } \\
\text { History: } \\
\text { National } \\
\text { September } \\
11 \text { Memorial }\end{array}$ & $\begin{array}{l}\text { Use equals assent to the TOS. } \\
\text { The only option to non-accep- } \\
\text { tance of terms is cessation of } \\
\text { use ("If you do not accept this } \\
\text { Agreement, do not use this } \\
\text { site"). }\end{array}$ & $\begin{array}{l}\text { Terms can change any time } \\
\text { ("from time to time") for any } \\
\text { reason ("at the sole discre- } \\
\text { tion"). }\end{array}$ & None required. & $\begin{array}{l}\text { Indemnification required } \\
\text { from users for harms result- } \\
\text { ing from use of website or } \\
\text { inability to use website. }\end{array}$ \\
\hline $\begin{array}{l}\text { Creative } \\
\text { Commons }\end{array}$ & $\begin{array}{l}\text { Using a work subject to a CC } \\
\text { license equates assent to } \\
\text { terms. The rights granted to } \\
\text { users in a CC license function } \\
\text { as consideration for purposes } \\
\text { of contract formation. }\end{array}$ & $\begin{array}{l}\text { If a CC license is used to } \\
\text { govern access to content, } \\
\text { then changes to terms must } \\
\text { be by mutual written consent } \\
\text { of the licensor and the user. }\end{array}$ & None required. & None required. \\
\hline Pinterest & $\begin{array}{l}\text { Access or use equals assent } \\
\text { to the TOS. Assent is for those } \\
\text { age } 13 \text { and older ("Any use } \\
\text { or access to the Service by } \\
\text { anyone under the age of } 13 \text { is } \\
\text { strictly prohibited"). } \\
\text { Use after change in terms } \\
\text { equals assent to those } \\
\text { changes. The only option } \\
\text { to non-acceptance of terms } \\
\text { is cessation of use ("If you } \\
\text { do not agree to any of these } \\
\text { Terms or to any future Terms } \\
\text { of Service, do not use or } \\
\text { access [or continue to access] } \\
\text { the Service"). }\end{array}$ & $\begin{array}{l}\text { Terms can change any time } \\
\text { ("from time to time") and } \\
\text { for any reason ("in its sole } \\
\text { discretion"). }\end{array}$ & $\begin{array}{l}\text { Any change in terms is } \\
\text { reflected by a change in } \\
\text { the last modified tag at the } \\
\text { bottom of the TOS page. } \\
\text { Burden is on the user to } \\
\text { check the last-date-modified } \\
\text { tag periodically. }\end{array}$ & $\begin{array}{l}\text { Indemnity required from } \\
\text { users including "reasonable } \\
\text { legal and accounting fees" } \\
\text { and costs for harms arising } \\
\text { from access or use, user } \\
\text { content or breach of terms. }\end{array}$ \\
\hline Wikimedia & $\begin{array}{l}\text { The only option to non- } \\
\text { acceptance of terms is } \\
\text { cessation of use ("if you do } \\
\text { not agree with our Terms } \\
\text { of Use, you cannot use our } \\
\text { services."). }\end{array}$ & $\begin{array}{l}\text { Change in terms is pos- } \\
\text { sible: "it may be necessary } \\
\text { to modify these Terms of } \\
\text { Use from time to time" and } \\
\text { "for legal or administrative } \\
\text { reasons, to correct an inac- } \\
\text { curate statement, or changes } \\
\text { in response to community } \\
\text { comments." }\end{array}$ & $\begin{array}{l}\text { Proposed changes } \\
\text { announced on Wikimedia } \\
\text { Announce-L. "However, we } \\
\text { ask that you please periodi- } \\
\text { cally review the most up-to- } \\
\text { date version of these Terms } \\
\text { of Use." } 30 \text {-day period for } \\
\text { comment. Revisions that are } \\
\text { "substantial" have a 60-day } \\
\text { comment period. Other } \\
\text { notices ("legal or administra- } \\
\text { tive...") have a 3-day notice } \\
\text { period. }\end{array}$ & None required. \\
\hline Yahoo! & $\begin{array}{l}\text { Access and use equals assent } \\
\text { to the TOS. } \\
\text { Assent limited to those of } \\
\text { "legal age to form a binding } \\
\text { contract." }\end{array}$ & $\begin{array}{l}\text { Terms can change at any } \\
\text { time ("modified from time to } \\
\text { time"). }\end{array}$ & $\begin{array}{l}\text { Terms may change without } \\
\text { "notice to you." However, } \\
\text { notice of changes "may" } \\
\text { be provided by "email, } \\
\text { regular mail, SMS, MMS, text } \\
\text { message, postings on the } \\
\text { Yahoo! Services, or other rea- } \\
\text { sonable means now known } \\
\text { or hereafter developed." }\end{array}$ & None required. \\
\hline
\end{tabular}




\begin{tabular}{|c|c|c|c|c|}
\hline & $\begin{array}{l}\text { Contract Formation: Assent } \\
\text { Issues }\end{array}$ & Change in terms & Notice of Changes in Terms & Indemnification \\
\hline Facebook & $\begin{array}{l}\text { Access and use equals assent } \\
\text { to the TOS. } \\
\text { Use after change in terms } \\
\text { equals assent to those } \\
\text { changes ("Your continued } \\
\text { use of Facebook following } \\
\text { changes to our terms consti- } \\
\text { tutes your acceptance of our } \\
\text { amended terms"). }\end{array}$ & $\begin{array}{l}\text { Terms can change "from time } \\
\text { to time." }\end{array}$ & $\begin{array}{l}\text { Changes can be made if } \\
\text { notice is posted on the } \\
\text { Facebook Site Governance } \\
\text { Page. However, another } \\
\text { provision indicates that "we } \\
\text { may provide notice on the } \\
\text { Site Governance Page." No } \\
\text { notice is required "legal } \\
\text { or administrative reasons, } \\
\text { or to correct an inaccurate } \\
\text { statement." }\end{array}$ & $\begin{array}{l}\text { Indemnity required from } \\
\text { users for harms, including } \\
\text { legal fees and costs for harm } \\
\text { resulting from "actions, } \\
\text { content or information on } \\
\text { Facebook." }\end{array}$ \\
\hline
\end{tabular}

TOS"), but also reference to what changes have been made. The TOS agreements reviewed here take a variety of approaches to offering notice; none except Wikimedia is useful, placing the burden on the user. Pinterest may modify or update terms "at its sole discretion." Taking a small step closer to actual notice of changes, Pinterest expects users to "review this page periodically," but the only indication that something might have changed is the "last modified" change date. In a similar vein, Facebook can make changes but must provide notice "by posting the change on the Facebook Site Governance Page and [offer] an opportunity to comment." Users must "like" the governance page to get a notice of changes. However, the next sentence appears to contradict the notice process, or at least make it less valuable: "If we make changes to policies referenced in or incorporated by this Statement, we may provide notice on the Site Governance Page." Wikimedia will also modify terms "from time to time" but it includes a process of notice and review by members: "we will provide notice of such modifications and the opportunity to comment via the Project websites, and via a notification on Wikimedia Announce-L." Yahoo! "may" notify users of changes, but it is not obliged to do so. Creative Commons, being a service that offers an agreement template for others to use, indicates that changes to the CC license cannot be made without the mutual written agreement of the licensorand auser("You").

\subsection{Indemnification}

A third aspect of legal integrity is whether the website requires indemnification from users, guaranteeing that the content submitted by users is lawful, i.e., it is noninfringing. Indemnification requires that a user warrant (promise) to hold harmless the provider of the repository service. This is an aspect of integrity that does indeed relate to the condition or legal quality of the content. It reminds the user that if unlawful/infringing content is submitted to the repository and the repository service is found to be legally responsible, the user is obliged to underwrite that liability by paying legal costs of the defense, any damages awarded, etc. The Make History: National September 11 Memorial requires users to indemnify it for harms relating to a user's use of the site. Facebook requires indemnification for "damages, losses, and expenses of any kind" including "reasonable legal fees and costs." Pinterest users must indemnify it for harms, including both legal and accounting fees or costs that might result from "access or use," "content," or "breach" of terms. Creative Commons, Wikimedia, and Yahoo! do not require indemnification from users of their service or website.

In online settings, service providers, like libraries, are immune from liability for content posted by third-party users in situations involving harms other than intellectual property infringement proceedings. In those instances involving content protected by copyright, service providers are similarly offered legal protection in the form of monetary damage remission if the service provider expeditiously removes the content or disables access to it upon receipt of prompt and proper notice. So why are service providers requiring indemnification from users as well? It might be less a matter of necessity and more a realization that the TOS agreements here, like many web service agreements, are mass-market, non-negotiable take-it-or-leave-it contracts. If the provider can get a user to agree (here by merely using the service), all is the better. In settings where the service provider is providing content to users, such as a database vendor, it is recommended that the user-library-licensee obtain an indemnification from the vendor for similar reasons of liability (Fig. 2). 


\subsection{Integrity Considerations for CCR}

Users should be aware of the mechanism for agreeing to be bound by the TOS, likewise to be bound by changes in the TOS. The repercussions of use-equals-assent (or agreement) should be evaluated. It is also important that material changes in the TOS in the CCR context should be communicated to the user and there should be a way for the user to terminate the agreement, remove the submitted content, and locate another service on which the content can be deposited under more acceptable terms. Whether or not indemnifications are necessary, a party should not enter into a commitment to indemnify the other party without careful review.

\section{Provenance}

Provenance includes two aspects of legal rights: awareness and ownership. Awareness is accomplished by notice. Here notice can refer to copyright or other rights or attribution. There may also be other rights related to how content can be conveyed to others (presentation or appearance). These rights would fall under the moniker of moral rights. "American copyright law, as presently written, does not recognize moral rights or provide a cause of action for their violation, since the law seeks to vindicate the economic, rather than the personal, rights of authors" (Gilliam v. American Broadcasting Companies, Inc.). As the right is personal to the artist, it is generally unalienable. "The moral rights include the right of integrity, the right of attribution, the right of disclosure (i.e., the right to decide if and when the work should be presented to the public), and the right of withdrawal (i.e., the right to remove the work from [the] public eye)" (Shoked, p. 821, n. 304). Ownership rights can identify not only who owns the copyright to the content users post, but also what rights are granted to other users regarding the content posted by a particular user. Assuming a user owns the copyright to the content that he or she posts, then the service can use the content as well as other user's? A grant of use right is made, but the original owner retains the copyright, so a non-exclusive right to use the content is made. It may restrict commercial use or prevent the creation of derivative works, for example.

The Make History: National September 11 Memorial requires use of copyright notice and prohibits alteration of the content when subsequent use is made of it ("copies of such documents or pages must not alter the original site content"). It does not permit its site to be framed by users and since use-equals-assent, anyone attempting to frame its site would be a party to its TOS agreements and thus prohibited from doing so. In the legal world of websites, framing can raise the ire of the framed-site owner as it can give the appearance that the content resides on another site when in fact it is merely framed by that site. One court explained:

Google does not store the images that fill this lower part of the window and does not communicate the images to the user; Google simply provides HTML instructions directing a user's browser to access a third-party website. However, the top part of the window (containing the information from the Google2 webpage) appears to frame and comment on the bottom part of the window. Thus, the user's window appears to be filled with a single integrated presentation of the full-size image, but it is actually an image from a third-party website framed by information from Google's website.

The process by which the webpage directs a user's browser to incorporate content from different computers into a single window is referred to as "in-line linking." The term "framing" refers to the process by which information from one computer appears to frame and annotate the in-line linked content from another computer (Perfect $10 \mathrm{v}$. Google, Inc.). Linking is preferred by this site as long as the juxtaposition of the link "does not falsely imply or suggest that the Foundation has endorsed or is affiliated with the linked site." Creative Commons requires that the URL to the link where the license is located be included in every copy distributed as well as notices related to a disclaimer of warranties. Public distributions and displays or adaptations must include authorship information, the title of the work, and- in the case of adaptation-reference to the original work. A user cannot "distort, mutilate, modify or take other derogatory action... which would be prejudicial to the Original Author's honor or reputation."

Yahoo!, Facebook and Pinterest do not require that users include any attribution information in photographs or other images users post. This is strange, as most litigation revolving around removal of copyright management information (CMI) or failing to transfer it when reusing/ reposting content involves the removal of gutter credits and other information from photographs (McClatchey v. The Associated Press, Cable v. Agence France Presse, Agence France Presse v. Morel). Certainly Yahoo!, Facebook, and Pinterest users all post photographs, some or many of which may not have been taken by the users. In other words, the photograph might be under copyright protection, owned by another.

Copyright management information (CMI) "means any of the following information ... including in digital 
form": 1) the title and other information identifying the work, including the information in the notice of copyright, or its author, owner; 2) with the exception of public performances of works by radio and television broadcast stations, the name of or identifying information about the performer whose performance is fixed other than an audiovisual work, in the case of an audio-visual work, the name of or identifying information about a writer, performer, or director who is credited in the audio-visual work; 3) terms and conditions for use of the work, 4) identifying numbers or symbols referring to such information or links to such information; and other information as the Register of Copyrights may prescribe by regulation (17 U.S.C. § 1202[c][1]-[8]). As one court concluded: "In this case, the mere fact that Murphy's name appeared in a printed gutter credit near the Image rather than as data in an 'automated copyright protection or management system' does not prevent it from qualifying as CMI or remove it from the protection of $\S 1202$ " (Murphy v. Millennium Records). The problem for users of Pinterest and similar sites is that it is unlawful to "intentionally remove or alter any copyright management information" (17 U.S.C. $\S 1202[b][1])$.

While the Pinterest TOS may not address this issue, if a Pinterest user posts content without a gutter credit or other CMI, the user could nonetheless face damages either in the form of actual damages (damages and profits), or "statutory damages for each violation of section 1202 in the sum of not less than $\$ 2,500$ or more than $\$ 25,000$ " (17 U.S.C. § 1203[c][3][B]). If there is a second repeat violation: second offense within 3 years after a final judgment, treble damages could be awarded (17 U.S.C. § 1203[c][4]). Perhaps recognizing this potential for liability, Wikimedia admonishes users that "attribution ... [is] giving credit where credit is due" and requires those who use or redistribute a Wikimedia page to include the URL to the original page or some other "stable online copy" of the content or provide a list of all authors.

\section{Copyright and Ownership}

Regarding ownership rights, the Make History: National September 11 Memorial claims copyright ownership of an array of content ("text, graphics, logos, button icons, images, photographs, audio clips, digital downloads, data compilations, and software"), but also claims ownership in any content that users submit as well ("site ['submissions'] will forever be the property and intellectual property of the Foundation"). This means that the service can develop and make a commercial use of an idea posted or expressed by a user on its service and it does not need to share any profits with the original user-owner. Yahoo! makes a similar claim over "ideas, suggestions, documents, and/or proposals ('Contributions') to Yahoo! through its suggestion or feedback webpages." Users "acknowledge and agree that ... Contributions automatically become the property of Yahoo!" In other words, if someone has an idea for improving its services, Yahoo! will gladly listen and perhaps use the idea, and it will claim ownership over it. True, the text of the post may be protected by copyright, but it would be the idea expressed in the post that is more valuable. The law recognizes the misappropriation of ideas and offers a remedy to plaintiffs who believe their ideas have been wrongfully taken.

Several more famous examples include the controversy over Milton Bradley's Dark Tower game (Burten v. Milton), the underlying story for the movie Philadelphia (Cavagnuolo et al. v. Rudin et al.), and the idea for the long-running television hit comedy The Cosby Show (Murray v. National). In these instances the appropriated idea was determined not to be novel or unique. Under existing legal concepts, the knowledge or "business idea" will be protected only if it is concrete, novel, and useful. Most cases arise in the entertainment industry where the idea for a game, television program, movie, book, commercial, or advertising campaign is misappropriated. Rather, the idea or commercial concept was either based on existing work or on basic common and "generic" ideas, and exhibited little creativity. The concept focuses on the initial investment by the original "creator," the subsequent taking and use of the information by a competitor in a competing product at little or no cost (the concept of "free-riding"), and the economic harm (a sort of "commercial immorality") that would result if the taking were not prohibited or limited in some way (National Basketball Association v. Motorola, Inc.). Companies do not want to face a claim of misappropriation, one reason that many companies forbid unsolicited suggestions or other ideas from being posted on a customer-comment or productreview website or submitted through the mail or in more traditional forms of contact. With a similar goal in mind, Yahoo! contractually through its TOS attempts to claim ownership of any ideas submitted.

While a public library might not desire to make commercial use of content submitted by its patrons or be interested in copyright ownership, the library would desire that the content, once submitted, could not be removed by the patron, and that the patron-submitter of the content would grant the library a non-exclusive right to use the content in the CCR as well as in library promotional material and perhaps additionally securing 
for others (other patrons) the right to use the content. Without rights for other patrons, the content submitted to the CCR becomes a view- or read-only source of content. As the CCR environment contains content protected by copyright, it might be thought that fair use would apply and justify use of the content in other contexts. However, the reality is that use of content by the posting patron as well as by other users is subject to the TOS agreement to which each user assents when submitting or accessing the content of others. Contract law, not copyright, governs initial and subsequent use of content submitted. Such uses should be therefore contemplated and allowed by language in the TOS agreement.

\subsection{Non-exclusive rights}

Yahoo! does not claim ownership of content that users "submit or make available," but it does require users to grant it a nonexclusive sub-licensable license to "use, distribute, reproduce, modify, adapt, publicly perform and publicly display such Content on Yahoo!" Photos, graphics, audio, or video submitted are governed by the same terms but are not subject to sub-license. A Make History: National September 11 Memorial user can, however, "print out individual pages but cannot copy or download a large portion of the site (e.g., no bots, webcrawlers, spiders, etc. that 'harvest' the site)." Any uses must be for "informational, non-commercial purposes" only. Creative Commons simply indicates that a work subject to a Creative Commons license is protected by copyright and/or other applicable law." Users of a work subject to a Creative Commons license are granted a nonexclusive and perpetual (as long as the work is protected by copyright) license to reproduce the work, make adaptations as long as the notice provisions are followed (see above), and make public distribution or performance of the work or an adaptation of it. Finally, a format modification right is included in which "such modifications as are technically necessary to exercise the rights in other media and formats."

Pinterest indicates that users retain rights to all the content that users post; of course, this assumes the user owned the content in the first place. Facebook likewise indicates that users "own all of the content and information" posted. All other content on Pinterest, other than "User Content," is the "property of Pinterest and its licensors." Pinterest likewise grants users a non-exclusive license right that is also "personal, noncommercial" to "use, display, reproduce, re-pin, modify (e.g., re-format), re-arrange, and distribute your User Content on Pinterest." A similar provision that allowed Twitter to make subsequent use of content posted was the focus of litigation in Agence France Presse v. Morel: "The Twitpic login page warns users that ' $[b] y$ clicking "Allow," you continue to operate under Twitter's Terms of Service.' Those terms provide: By submitting, posting, or displaying Content on or through the Services, you grant us a worldwide, non-exclusive, royalty-free license (with the right to sublicense) to use, copy, reproduce, process, adapt, modify, publish, transmit, display and distribute such content in any and all media or distribution methods ..." (Agence France Presse v. Morel). The court concluded however that the use rights were restricted to Twitter's partners and sub-licensees and not to other users.

While the Wikimedia TOS agreement says nothing about ownership rights, it does "grant broad permissions to the general public to re-distribute and re-use their contributions freely, so long as that use is properly attributed and the same freedom to re-use and re-distribute is granted to any derivative works." Users are required to grant Wikimedia an irrevocable license to the content submitted. Facebook likewise requires a grant of a

Fig. 3: Provenance Aspects of Public Sharing Website TOS, Examples.

\begin{tabular}{|c|c|c|c|c|}
\hline Website & Attribution Requirements & $\begin{array}{l}\text { Moral Rights: Presentation } \\
\text { or Appearance }\end{array}$ & Copyright and Ownership & $\begin{array}{l}\text { Non-exclusive rights given } \\
\text { to website or to other users' } \\
\text { content }\end{array}$ \\
\hline $\begin{array}{l}\text { Make History: } \\
\text { National } \\
\text { September } 11 \\
\text { Memorial }\end{array}$ & $\begin{array}{l}\text { Use must include the } \\
\text { Foundation copyright notice: } \\
\text { (C) 2004-2011, National } \\
\text { September } 11 \text { Memorial \& } \\
\text { Museum at the World Trade } \\
\text { Center Foundation, Inc. All } \\
\text { Rights Reserved. }\end{array}$ & $\begin{array}{l}\text { Use must not "alter the } \\
\text { original site content." } \\
\text { Framing prohibited. Linking } \\
\text { prohibited in a way to imply } \\
\text { or suggest endorsement or } \\
\text { affiliation. }\end{array}$ & $\begin{array}{l}\text { Claims copyright in its } \\
\text { content. } \\
\text { Claims copyright in content } \\
\text { that users post ("will } \\
\text { forever be the property and } \\
\text { intellectual property of the } \\
\text { Foundation") without com- } \\
\text { pensation. }\end{array}$ & $\begin{array}{l}\text { Printing or downloading of } \\
\text { content for informational, } \\
\text { non-commercial purposes. }\end{array}$ \\
\hline
\end{tabular}




\begin{tabular}{llll}
\hline Website $\quad$ Attribution Requirements & $\begin{array}{l}\text { Moral Rights: Presentation } \\
\text { or Appearance }\end{array}$ & $\begin{array}{l}\text { Copyright and Ownership } \\
\text { Non-exclusive rights given } \\
\text { to website or to other users' } \\
\text { content }\end{array}$ \\
\hline
\end{tabular}

\begin{tabular}{ll}
\hline Creative & Distributions, public perfor- \\
Commons & mances and displays require \\
& inclusion of the Uniform \\
& Resource and applicable \\
& copyright notices (name \\
& of author, title, and source \\
& work if an adaptation) and \\
& keeping disclaimer of war- \\
& ranties intact.
\end{tabular}

\begin{tabular}{lll}
\hline Pinterest $\quad$ None required. & None required. & Users retain copyright in \\
& content posted by users; \\
& Pinterest retains copyright to \\
& its content.
\end{tabular}

Presentation rights prohibit Works subject to a Creative distortion, mutilation, modification, or "other derogatory action" that is "prejudicial to the... honor or reputation" of the author. Commons license are protected by copyright.

Rights granted to user or licensee: nonexclusive license to reproduce, adapt, to make public display or public performance, and to otherwise modify the work if necessary to access and use the work in "other media and formats.”

Nonexclusive, sub-licensable license granted to Pinterest

to "use, display, reproduce, re-pin, modify (e.g., re-format), re-arrange, and distribute" user content. Personal, noncommercial license granted to users.

\begin{tabular}{|c|c|c|c|c|}
\hline Wikimedia & $\begin{array}{l}\text { Attribution of authors } \\
\text { required by use of URL, or } \\
\text { hyperlink or through a list of } \\
\text { all authors, though the } \\
\text { "list of authors may be } \\
\text { filtered to exclude very small } \\
\text { or irrelevant contributions." } \\
\text { Public domain content } \\
\text { submitted by users must be } \\
\text { so labeled. }\end{array}$ & None required. & None stated. & $\begin{array}{l}\text { Requires users to "grant } \\
\text { broad permissions to } \\
\text { the general public to } \\
\text { re-distribute and re-use their } \\
\text { contributions." }\end{array}$ \\
\hline \multirow[t]{2}{*}{ Yahoo! } & None required. & None required. & $\begin{array}{l}\text { Users retain ownership } \\
\text { of content submitted but } \\
\text { Yahoo! owns "ideas, sug- } \\
\text { gestions, documents, and/ } \\
\text { or proposals" submitted } \\
\text { through its suggestion or } \\
\text { feedback webpage. }\end{array}$ & $\begin{array}{l}\text { Requires users to grant } \\
\text { Yahoo! a nonexclusive } \\
\text { license to use, distribute, } \\
\text { reproduce, modify, adapt, } \\
\text { publicly perform, and pub- } \\
\text { licly display such Content on } \\
\text { the Yahoo! site. Other than } \\
\text { photos, graphics, audio, } \\
\text { or video, such content is } \\
\text { subject to sub-license as } \\
\text { well. }\end{array}$ \\
\hline & & & & $\begin{array}{l}\text { Yahoo! grants users a } \\
\text { license to use the object } \\
\text { code of its software subject } \\
\text { to various exclusions such } \\
\text { as copy, modify, or create a } \\
\text { derivative. }\end{array}$ \\
\hline Facebook & None required. & None required. & $\begin{array}{l}\text { Users retain ownership of } \\
\text { content posted. }\end{array}$ & $\begin{array}{l}\text { Nonexclusive, sub-licensable } \\
\text { license granted to Facebook } \\
\text { in intellectual property } \\
\text { rights, like photos and } \\
\text { videos. }\end{array}$ \\
\hline
\end{tabular}


nonexclusive, sub-licensable license to use any IP content ["intellectual property rights, like photos and videos"] that one posts on or in connection with Facebook. A CCR might likewise require proper copyright and prohibit users from altering or removing existing notices and refrain from framing or other practices that might make less clear that the source of content used by others is the CCR. The public library might also desire to secure rights to reuse content submitted by its patrons. Whether the library wants to take the extreme position that it owns all content submitted by users is another question. Requiring patrons to surrender their copyright might dissuade some from making submissions.

\subsection{Provenance Considerations for CCR}

Use of copyright notice is a good practice and a provision that prevents removal and avoids unintended CMI issues. Since a public library would unlikely desire to claim ownership of the content that patrons submit, the copyright notice would indicate the name, date, and (c) symbol of the patron who is claiming ownership of the work. The TOS agreement would require subsequent users to include the notice. Attribution requirements where copyright may not be involved may encourage users to submit content if they know that subsequent use of the work will require other users to include proper attribution. The public library may desire another form of attribution: attribution not only to the user-contributor, but also to it in its institutional capacity as host of the repository. It may also make it easier for third parties to locate the source of content as emanating from the CCR, which may lead those users to other useful content in the CCR. The public library like the commercial services reviewed here should obtain the permission to forever host the user content, to use the content, and to have the right to authorize other users to do the same, again subject to reasonable limitations such as no commercial use. The use granted to the CCR host and other users should be perpetual or irrevocable (Fig. 3).

\section{Permanence}

\subsection{Changes in Content}

It could be claimed that the final characteristic of a useful CCR, the retention and continued availability of submitted content, is its most important feature. Without permanence, the mechanism does not function much as repository. There are several aspects to the permanence of content submitted to a CCR. In general, can content be removed? If removal is possible, under what circumstances is removal accomplished? We view "removal" in two ways. Simple removal is typically described in the TOS as "changes" to content from internal forces. This could result from the provider's enforcing restrictions on content as discussed above, or the provider may simply edit the content submitted. Removal also occurs when there is wholesale deletion of content. Here deletion can be complete such as when a user is terminated and all her content is removed or otherwise made inaccessible. Another removal occurs item by item and is motivated by external forces. In most instances this is in response to a claim of infringement and the image, audio or video clip, etc., is removed or made inaccessible. In specific, the question is whether the service provider or website is following the commands of section 512 of the copyright law, where the so-called take-down rules are found. Here the service provider indicates its desire to comply with the elaborate provisions of the statute, gain protection from any award of monetary damage, costs, or fees, register its service with the U.S. Copyright Office, and designate a person to receive complaints and respond accordingly. Do the TOS make specific reference to this statute and process? More important from the user perspective in addition to expressing obligations to expeditiously remove or disable access to content claimed to be infringing, is mention also made of the restoration provisions of section 512?

\subsection{Removal Provisions General}

As might be expected, the Creative Commons license does not refer to either general (change or removal) or specific content (removal or restoration) provisions. The Make History: National September 11 Memorial possesses broad rights to change content ("may make changes at any time"). There is however no specific removal provision. Following termination of a user or if the user removes his own content, Pinterest indicates that it "may" retain user content for a "commercially reasonable period of time for backup, archival, or audit purposes." On the other hand, Pinterest can also remove content it believes violates the TOS or its Acceptable Use Policy. Likewise Facebook can remove content posted by a user that violates its TOS or other policies. Pinterest can, "in appropriate circumstances and at its discretion, disable and/or terminate the accounts of users who repeatedly infringe or are repeatedly charged with infringing the copyrights or 
other intellectual property rights of others." The "repeat infringer" proviso is also a result of attempted compliance with section 512. Requiring a service provider to have a policy in place that terminates repeat infringers is a qualifying requirement of the statute. While the TOS does not reference section 512, this provision nonetheless parallels the repeat infringer provision of section 512 requiring that a service have "adopted and reasonably implemented, and informs subscribers and account holders of the service provider's system or network of, a policy that provides for the termination in appropriate circumstances of subscribers and account holders of the service provider's system or network who are repeat infringers" (17 U.S.C. § 512[i][1] [A]). Facebook has a similar repeat-infringer policy ("If you repeatedly infringe other people's intellectual property rights, we will disable your account when appropriate").

Wikimedia perhaps offers the best opportunity for permanence in the face of termination as it will "strive to make and keep educational and informational content" available "in perpetuity." There is no promise or warrant that it will do this however. Moreover, a subsequent provision indicates that Wikimedia will have "no responsibility or liability for the deletion of, or the failure to store or to transmit, any content or communication maintained by the service." Yahoo! likewise claims no responsibility for either "the deletion or failure to store any messages and other communications or other Content maintained or transmitted by the Yahoo! Services." Moreover Yahoo! can in its "sole discretion refuse, or remove any content"; it can also remove content that violates the TOS or is otherwise objectionable. While Facebook does not possess a right to delete content per se it does require that a user "delete all data you receive from us concerning a user if the user asks you to do so, and will provide a mechanism for users to make such a request."

When content posted is someone else's, it is possible that the "someone else" will claim the work is infringing. The posting (use) of the work may of course be deemed a fair use under the copyright law (17 U.S.C. § 107) but some providers may not want to take that risk and defer to the safe harbor of section 512 which then obliges them to remove the work to seek protection from the damage awards the statute provides. Participation in the section 512 take-down process is not required; it is optional, but then the protection of the law is not guaranteed.

\subsection{Restoration in Response to Specific Removal}

Several services make specific reference to the takedown and restoration mechanisms of section 512, often including statutory process and instructions by which copyright owners can contact the service provider and request that content be removed. The Make History: National September 11 Memorial references the section 512(c) process and includes the statutory requirements for a valid take-down notice. Even provided is the name of the designated agent to whom removal or disabling requests should be sent. However, there is no mention of the section $512(\mathrm{~g})$ provisions, by which a user can indicate through a counter-notification process that the content was removed in error, i.e., that it is not infringing, and that the content be restored or disabling deactivated. Yahoo! also includes reference to the DMCA (Digital Millennium Copyright Act) that in 1998 enacted section 512 of the copyright law as well as the statutory requirements and the contact information for filing a take-down request with its designated agent, but it likewise fails to mention the restoration process of section 512(g). Pinterest offers a similar statement and list of statutory requirements for a valid take-down notice, including sample language that can be used in the notice that allows the copyright owner to more or less fill in the blanks. Pinterest alone includes reference to the counter-notification process by which content or access can be restored, and the statutory elements of a valid counter-notification are included.

Wikimedia references the DMCA but not section 512 in specific. It also mentions a repeat-infringer policy but without specific reference to section 512(i). Wikimedia does not include the statutory elements of a valid takedown notice. However, Wikimedia does alert users to the counter-notification process and offers that "if you think a DMCA notice has been improperly filed, you may wish to consult the Chilling Effects website." While Facebook mentions the DMCA, there is no reference to take-down processes; reference is to the repeat-infringer policy only. It does reference generally the restoration provision, i.e., "we will provide you with an opportunity to appeal." The restoration right is important as the service provider is obliged to restore the content within 10-14 business days unless the complainant indicates that he or she "has filed an action seeking a court order to restrain the subscriber from engaging in infringing activity relating to the material on the service provider's system or network" 
Fig. 4: Permanence Aspects of Public Sharing Website TOS, Examples.

\begin{tabular}{|c|c|c|c|c|}
\hline Website & Changes in Content & Removal provision-general & $\begin{array}{l}\text { Removal provision-specific: } \\
\text { Section } 512 \text { take-down } \\
\text { process }\end{array}$ & Restoration \\
\hline $\begin{array}{l}\text { Make History: } \\
\text { National } \\
\text { September } 11 \\
\text { Memorial }\end{array}$ & $\begin{array}{l}\text { Change in content can be } \\
\text { made "at any time." }\end{array}$ & None. & $\begin{array}{l}\text { Specific reference to section } \\
512(c) \text { includes statutory } \\
\text { requirements for a valid } \\
\text { take-down request. Provides } \\
\text { name and contact for des- } \\
\text { ignated agent to "receive } \\
\text { notifications of claimed } \\
\text { infringement." }\end{array}$ & $\begin{array}{l}\text { No mention of the section } \\
512 \text { restoration provisions } \\
\text { of sub-section (g), i.e., a } \\
\text { counter-notification. }\end{array}$ \\
\hline $\begin{array}{l}\text { Creative } \\
\text { Commons }\end{array}$ & None. & None. & None. & None. \\
\hline Pinterest & $\begin{array}{l}\text { "May retain content follow- } \\
\text { ing termination for a com- } \\
\text { mercially reasonable period } \\
\text { of time for backup, archival, } \\
\text { or audit purposes." }\end{array}$ & $\begin{array}{l}\text { Can remove content that vio- } \\
\text { lates TOS or Acceptable Use } \\
\text { Policy. Termination provision } \\
\text { for repeat infringers similar } \\
\text { to, but does not mention, } \\
\text { section } 512 \text { (i). }\end{array}$ & $\begin{array}{l}\text { Reference to DMCA but } \\
\text { not section } 512 \text { by name. } \\
\text { Includes statutory require- } \\
\text { ments for valid take-down } \\
\text { request and sample } \\
\text { language to include in the } \\
\text { request. Identifies des- } \\
\text { ignated agent (name and } \\
\text { contact information). }\end{array}$ & $\begin{array}{l}\text { Processes for filing of coun- } \\
\text { ter-notification detailed, } \\
\text { including statutory elements } \\
\text { of a valid counter-notifica- } \\
\text { tion. No reference to specific } \\
\text { statutory provision. }\end{array}$ \\
\hline Wikimedia & $\begin{array}{l}\text { "Strives to keep" educa- } \\
\text { tional and informational } \\
\text { content "in perpetuity" but } \\
\text { no responsibility for deletion } \\
\text { or failure to store content. }\end{array}$ & None. & $\begin{array}{l}\text { Reference to DMCA and } \\
\text { removal process generally. } \\
\text { Includes contact information } \\
\text { for designated agent and } \\
\text { repeat infringer provision. }\end{array}$ & $\begin{array}{l}\text { "[S]trongly encourage[s] } \\
\text { users to file counter-notifi- } \\
\text { cations when they appro- } \\
\text { priately believe a DMCA } \\
\text { takedown demand is invalid } \\
\text { or improper." }\end{array}$ \\
\hline Yahoo! & $\begin{array}{l}\text { No responsibility or liability } \\
\text { for the deletion or failure to } \\
\text { store content. }\end{array}$ & $\begin{array}{l}\text { Possesses "sole discretion" } \\
\text { to pre-screen, refuse, or } \\
\text { remove content that violates } \\
\text { the TOS or is otherwise } \\
\text { objectionable. }\end{array}$ & $\begin{array}{l}\text { General reference to DMCA } \\
\text { process, statutory require- } \\
\text { ments for a valid take-down } \\
\text { request and contact informa- } \\
\text { tion for designated agent. }\end{array}$ & $\begin{array}{l}\text { Fails to mention restora- } \\
\text { tion (counter-notification) } \\
\text { process. }\end{array}$ \\
\hline Facebook & $\begin{array}{l}\text { None, but users are required } \\
\text { to delete content if another } \\
\text { user asks that user to do so. }\end{array}$ & $\begin{array}{l}\text { Can remove content that vio- } \\
\text { lates TOS or other policies. }\end{array}$ & $\begin{array}{l}\text { Reference to the DMCA, but } \\
\text { not the removing or dis- } \\
\text { abling provisions but only to } \\
\text { the repeat infringer policy. }\end{array}$ & $\begin{array}{l}\text { General reference to restora- } \\
\text { tion provision, i.e., "we will } \\
\text { provide you with an opportu- } \\
\text { nity to appeal." }\end{array}$ \\
\hline
\end{tabular}

(17 U.S.C. § 512[g][2][C]). Most copyright owners are not interested in pursuing legal action, but if an owner can get content removed by simply sending a statutory notice, that effort is worth the result, i.e., expeditious removal of content or disabling of access. As Lipinski observes, filing a request for a court-enforced take-down or disabling order is a much larger undertaking, in terms of attorney fees, filing costs, time, etc. and may lead to protracted proceedings beyond the simple preparation and filing of the initial request (2006, 187-230) (Fig. 4).

\subsection{Permanence Considerations for CCR}

With respect to permanence, a CCR needs to retain content as submitted to retain its value as a repository. Short of legal prohibitions regarding the possession of some content, child pornography for example, the library may desire to retain other content even if it is unlawful to perform or display obscenity, for example, as there may be a state statutory exemption to do so as discussed above. Furthermore, the law may change and at some point in the future what is obscene or otherwise unlawful 
today might not be obscene tomorrow, so again there may be value in retaining such content. As discussed here, there may be other controversial content that is nonetheless protected by the First Amendment yet typically prohibited by service providers or websites. Due to concepts of intellectual freedom, a public library might not want to suppress or stifle this content. To minimize copyright liability, the library should take advantage of section 512 to protect itself but also, as have some of the websites discussed here, undertake aggressive measures to help patrons restore content when the challenge is questionable. This can include preparation of a form that complies with the statutory requirements for a valid restoration (counter-notification) request to facilitate this process. Promoting the restoration provisions would maximize the accessibility of content that a copyright holder claims to be infringing as many copyright owners will not take the next step of filing a court order request. Remember too that section 230 immunizes a service provider like a public library against other sorts of unlawful content posted by patrons, content that is defamatory or otherwise tortuous. Unlike the requirements of section 512 and the copyright law that requires a service provider to remove or disable content to secure its protection, the statute provides against damages; section 230 requires no such removal or disabling. The service provider need do nothing, even upon notice of the unlawful nature of the content posted. Moreover, the benefit to the provider is complete immunity coupled with no legal obligation to remove such content. Section 230 is a powerful tool in securing the availability of content in online settings.

\section{Conclusion}

While many of the features of a successful CCR exist across the services discussed here, none possesses all the required elements (functionality, integrity, provenance, permanence) or sub-elements. While most websites allow for a variety of submission options, the public library may be positioned to take advantage of additional legal protections. Decision-making regarding controversial content in public library collections may also be influenced by professional responsibility as well as First Amendment sensitivities to avoid viewpoint discrimination. A for-profit entity may not be so obliged in spirit or obligated under the law. The result is a robust array of topics, viewpoints, etc. represented in the physical collection of the public library and in its CCR.

While all services disclaim warranties regarding the information submitted by users, a public library would do the same. It is unlikely the public institutional CCR aims to take on the role of editor, much less be a guarantor of the veracity or soundness in terms of error of the content it houses in its repository. However, public libraries might not be as interested in terminating users or at least might have a more limited set of circumstances in which termination would be necessary. The library would adopt a graduated suspension mechanism instead or at least as a precursor to termination consistent with the general liberty interest and due process sensitivities that govern patron access to the physical public library space.

Another drawback to the TOS agreements reviewed involves contractual integrity. A CCR should provide contributors the ability to read the TOS before engaging a distinct "I agree" or "I click-to-agree" mechanism of assent. Any change in terms should be communicated to the patron-contributor offering an opportunity (where the change relates to a material term) to agree or disagree and terminate his participation in further depository contribution. If the patron decides to stop making submissions, the library should have the right to retain the content contributed thus far.

Alignment between a commercial and public institutional CCR is achieved mostly in the area of provenance, especially in the notice and attribution requirements. Far less alignment is in the ownership section. The library should have a perpetual nonexclusive license to use and make available patron-supplied content to further its mission and general goals, for marketing purposes for example, but perhaps not for commercial purposes. There is little need for the library to become the copyright owner of patron-supplied content. Such provision may limit the attraction of the repository, though this has not dampened the attraction of some commercial services as discussed above. While a public library can benefit from the protection of statutes such as section 512 and section 230 , it may not be necessary to have complete discretion to determine the contents of the repository or to require patron to indemnify the public library. Legal counsels may insist that patrons make such indemnifications. Again, this can undermine the goal of patron repositories. In addition, public institutions such as schools and libraries may also possess tort immunity under the Eleventh Amendment to the Constitution as well as by state statute. 
Fig. 5: Summary of TOS Recommendations for Co-created Community Repositories

\section{TOS Characteristics Recommendations}

\begin{tabular}{|c|c|}
\hline \multirow[t]{6}{*}{ Functionality } & $\begin{array}{l}\text { Content considered for inclusion should differentiate between unlawful, not allowed (hate speech and nudity), and } \\
\text { restrictions put in place by libraries to serve community information needs. }\end{array}$ \\
\hline & Limited Public Forum established in relation to the First Amendment. \\
\hline & $\begin{array}{l}\text { Do not guarantee } 100 \% \text { accuracy but request of patrons that the content uploaded has not been altered from its } \\
\text { original source or post. }\end{array}$ \\
\hline & Disclaim legal responsibility for services or content errors. \\
\hline & Use of liberal content provision may result in the need to implement for patron-imposed filtering. \\
\hline & $\begin{array}{l}\text { If necessary to preserve the termination right, then to encourage community participation in a CCR, you may want to } \\
\text { consider including a suspension provision that, short of termination, offers a graduated system of penalties similar } \\
\text { to policies in place relating to patron access to facilities and including notice and cure in its termination provision. }\end{array}$ \\
\hline \multirow[t]{2}{*}{ Integrity } & Users should be aware of the mechanism for agreeing to be bound by the TOS, and by changes in the TOS. \\
\hline & $\begin{array}{l}\text { It is also important that material changes in the TOS in the CCR context should be communicated to the user and } \\
\text { there should be an ability to terminate the agreement and remove the content the user has submitted. }\end{array}$ \\
\hline \multirow[t]{5}{*}{ Provenance } & $\begin{array}{l}\text { Use of copyright notice is a good practice and a provision that prevents removal of such notices can avoid unin- } \\
\text { tended copyright management issues. }\end{array}$ \\
\hline & Copyright notice would indicate the name, date, and $₫$ symbol of the patron who is claiming ownership of the work. \\
\hline & $\begin{array}{l}\text { Consider another form: attribution-not to the user-contributor but to it in its institutional capacity as host of the } \\
\text { repository. }\end{array}$ \\
\hline & $\begin{array}{l}\text { Obtain permission to forever host and make use of the user content and to possess the right to authorize other } \\
\text { users to do the same, subject to reasonable limitations such as no commercial use. }\end{array}$ \\
\hline & Use granted to the CCR host and other users should be perpetual or irrevocable. \\
\hline \multirow[t]{5}{*}{ Permanence } & Need to retain content as submitted as this relates to its value as a repository. \\
\hline & $\begin{array}{l}\text { Controversial content protected by the First Amendment is typically prohibited by service providers or websites. Due } \\
\text { to concepts of intellectual freedom and preserving cultural heritage, a public library might not want to suppress or } \\
\text { stifle this content. }\end{array}$ \\
\hline & To minimize copyright liability, the library should take advantage of section 512 to protect itself. \\
\hline & Undertake aggressive measures to help patrons restore content when the challenge is questionable. \\
\hline & $\begin{array}{l}\text { Remember that section } 230 \text { immunizes a service provider like a public library against other sorts of unlawful } \\
\text { content posted by patrons, content that is defamatory or otherwise tortuous. }\end{array}$ \\
\hline
\end{tabular}

This also weighs against the need for patron indemnification. Overall, the best future for a CCR is to have the public institution itself be the provider of the repository service. The TOS reviewed are instructive nonetheless to demonstrate the array of provisions and issues that need to be considered before a public entity embarks on such an endeavor. The discussion and recommendations here may provide public libraries, archives, museums, and other public institutions with an awareness of the problems as well as possibilities in designing the operating rules of a CCR (Fig. 5).

\section{References}

17 U.S.C. § 106 A.

17 U.S.C. $\$ 512$

17 U.S.C. $\S 512(\mathrm{c})(1)(\mathrm{A})(\mathrm{ii})$.

17 U.S.C. $\$ 512(\mathrm{~g})(2)(\mathrm{C})$.

17 U.S.C. $\S 512(\mathrm{i})(1)(\mathrm{A})$.

17 U.S.C. $\S 1202(\mathrm{~b})(1)$.

17 U.S.C. $§ 1202(c)(1)-(8)$.

17 U.S.C. $\$ 1203(\mathrm{C})(3)(\mathrm{B})$.

17 U.S.C. $\S 1203(\mathrm{C})(4)$.

31 U.S.C. § 1341.

31 U.S.C. § 1341(a)(1). 
47 U.S.C. § 230.

47 U.S.C. § $230(f)(2)$.

720 Illinois Compiled Statutes 5/11-21(c)(3).

Agence France Presse v. Morel, 2013 WL 146035 (S.D.N.Y.).

Agence France Presse v. Morel, 769 F.Supp.2d 295, 299 (S.D.N.Y., 2011).

Apple Terms and Conditions. Available at http://www.apple.com/ legal/internet-services/itunes/us/terms.html\#GIFTS (accessed July 13, 2013).

Baumrin, Julian. "Note \& Comment: Internet Hate Speech and the First Amendment, Revisited." Rutgers Computer and Technology Law Journal 37 (2011): 223, 250.

Biederman, Donald E. “Interactive On-Line Entertainment," 367-368, in Counseling Clients in the Entertainment Industry (2001) (647 [Practising Law Institute/Patent Assertion] PLI/Pat 263).

Black's Law Dictionary 502 ( $9^{\text {th }} \mathrm{ed}$. 2009) (no pagination in Westlaw).

Blum, George L. Obscenity Prosecutions: Statutory Exemption Based on Dissemination to Persons or Entities Having Scientific, Educational, or Similar Justification of Possession of Such Materials, 13 A.L.R. 5th 567 (1993) (updated weekly in Westlaw).

Bradley, Kevin. "Defining Digital Sustainability." Library Trends 56.1 (2007):148-163.

Burten v. Milton Bradley Company, 763 F.2d 461 (1st Cir. 1985).

Cable v. Agence France Presse, 728 F.Supp.2d 977, 981 (N.D.Ill., 2010).

Cavagnuolo et al. v. Rudin et al., No. 94 Civ. 0585 (S.D.N.Y. 1994).

Chen, Su-Shing. "The Paradox of Digital Preservation." Computer (March 2001): 24-28.

Classen, H. Howard. A Practical Guide to Software Licensing for Licensees and Licensors. $3^{\text {rd }}$ ed. Chicago: American Bar Association, 2008, quoting K\&K Management, Inc. v. Lee, 557A. $2 d$ (Md. 2989) and Williston on Contracts $\S 866$, p. 65.

Copeland, Andrea J. "Analysis of Public Library Users' Digital Preservation Practices." Journal of the American Society for Information Science \& Technology 62.7 (2011): 1288-1300.

Copeland, Andrea J., and Deborah Barreau. "Helping People to Manage and Share their Digital Information: A Role for Public Libraries." Library Trends 59.4 (2011): 637-49.

Cox, Richard J. "Digital Curation and the Citizen Archivist." Proceedings of DigCCurr2009 Digital Curation: Practice, Promise and Prospects (2009): 102-09.

Danne, Jr., William H. "Annotation, What Are Additional Terms Materially Altering Contract within Meaning of UCC § 2-207(2) (b)," 72 A.L.R.3d 479 (first published 1976, updated weekly in Westlaw).

Dejohn v. Temple University, 537 F.3d 301 (3d Cir. 2008).

Doe v. University of Michigan, 721 F. Supp. 852 (E.D. Mich. 1989).

Douglas v. Talk America, Inc., 495 F.3d 1062 (9th Cir. 2007), cert. denied 552 U.S. 1242 (2008).

Douglas v. Talk America, Inc., 495 F.3d 1062, 1065 (9th Cir. 2007), cert. denied 552 U.S. 1242 (2008)

Douglas v. Talk America, Inc., 495 F.3d 1062, 1065 (9th Cir. 2007), cert. denied 552 U.S. 1242 (2008).

Douglas v. Talk America, Inc., 495 F.3d 1062, 1066, n. 1 (9th Cir. 2007), cert. denied 552 U.S. 1242 (2008).

Fang, Albert. "Let Digital Technology Lay the Moral Right of Integrity to Rest." Connecticut Journal of International Law 26, (2011): 457.
Garde-Hansen, Joanne. "My Memories? Personal Digital Archive Fever and Facebook." In Digital Memory Practices. Ed. by Joanne Garde-Hansen, Andrew Hoskins, and Anna Reading. New York: Palgrave Macmillan, 2009, pp. 135-50.

Gerard, Julie B., and Scott D. Bergthold. "Local Regulation and Adult Business," § 3:42 (Obscenity; Exemptions for regulatory scheme) (database updated November 2012).

Gilliam v. American Broadcasting Companies, Inc., 538 F.2d 14, 24 (2d Cir. 1976).

Good, Katie Day. "From Scrapbook to Facebook: A History of Personal Media Assemblage and Archives." New Media \& Society 15.4 (2013): 557-73.

Headley, Tim. "Reverse Domain-Name Hijackers Get Caught." The National Law Journal, April 30, 2001, at C10 (no pagination in LexisNexis version).

HowTo.gov., last updated August 5, 2013. http://www.howto.gov/ social-media/terms-of-service-agreements/negotiated-termsof-service-agreements (accessed 8/13).

Iota XI Chapter of Sigma Chi Fraternity v. George Mason University 773 F. Supp. 792 (E.D. Va. 1991), aff'd 993 F.2d 386 (4th Cir. 1993).

Japzon, Andrea J. "A Model of and Support for a Digital Preservation Infrastructure that Connects Individuals to Libraries." Proceedings of the World Library and Information Congress: $74^{\text {th }}$ General Conference and Council (2008). http://www.ifla. org/IV/ifla74/papers/084-Japzon-en.pdf (accessed October 20, 2013).

Kennedy, Lyndon, Mor Naaman, Shane Ahern, Rahul Nair, and Tye Rattenbury. "How Flickr Helps Us Make Sense of the World: Context and Content in Community-Contributed Media Collections." Paper presented at the annual meeting of ACM Multimedia in Augsburg, Bavaria, Germany, September 23-28, 2007. Published in Multimedia '07, Proceedings of the 15th International Conference on Multimedia. New York: ACM, 2007, pp. 631-40.

Lipinski, Tomas A. The Complete Copyright Liability Handbook for Librarians and Educators. New York: Neal-Schuman Publishers, Inc., 2006.

Lipinski, Tomas A. The Librarian's Legal Companion for Licensing Information Resources and Services. New York: Neal-Schuman Publishers, Inc., 2012.

Lipinski, Tomas A. "Click Here to Cloud: Issues in Cloud Computing EULAs or TOS Agreements." Fourth Annual International Symposium on Information Management in a Changing World (IMCW), Limerick, Ireland, September 4-6, 2013.

McClatchey v. The Associated Press, 2007 WL 776103, *5 (W.D. Pa., 2007) (un published).

McCauley v. University of the Virgin Islands, 618 F.3d 232 (3d Cir. 2010).

McKemmish, Sue. "Evidence of Me ..." Archives and Manuscripts 24.1 (May 1996): 28-45.

Mason, Ingrid. "Cultural Information standards-Political Territory and Rich Rewards." In Theorizing Digital Cultural Heritage. Ed. by F. Cameron and S. Kenderdine. Cambridge, MA: MIT Press, 2007, pp. 223-44.

Murphy v. Millennium Records, LLC, 2011 WL 2315128, *6 (3d Cir.)

Murray v. National Broadcasting Co., Inc., 178 A.D.2d 157 (N.Y.A.D. 1 Dept., 1991).

Museum Boutique Intercontinental, Ltd. v. Picasso, 880 F. Supp. 153, 157 at n. 3 (S.D.N.Y. 1995). 
National Basketball Association v. Motorola, Inc., and Sports team Analysis, 939 F. Supp. 1071 (S.D.N.Y. 1996), rev'd 105 F. 3d 841, 845 (2nd Cir. 1997).

Perfect 10 v. Google, Inc., 508 F.3d 1146, 1156 (9th Cir. 2007) (citations omitted).

Pfeifer v. City of West Allis, 91 F. Supp. 2d 1253, 1259 (E.D. Wis. 2000), citing Perry Education Association v. Perry Local Educators Association, 460 U.S. 37 (1983).

ProCD, Inc. v. Zeidenberg, 86 F. 3d 1447 (7th Cir. 1996).

Shoked, Nadav. "The Community Aspect of Private Ownership." Florida State University Law Review (2011) 38, 759, 821, at $\mathrm{n}$. 304.

Sirvinskaite, Irma. "Toward Copyright ‘Europeanification': European Union Moral Rights." Journal of International Media \& Entertainment Law 3.2,(2010-2011): 263-88.

Terras, Melissa. "The Digital Wunderkammer: Flickr as Platform for Amateur Cultural and Heritage Content." Library Trends 59.4 (2011): 686-706.

UWM Post, Inc. v. Board of Regents of University of Wisconsin System, 774 F. 6Supp. 1163 (E.D. Wis.1991).

U.S. Copyright Office. Online Service Providers: Service Provider Designation of Agent to Receive Notification of Claims of Infringement. Available at http://www.copyright.gov/onlinesp/ (accessed May 14, 2013).

U.S. v. Kolinda, 497 U.S. 720, 740-41 (1990) (Brennan, J., dissenting), quoting Perry Education Association v. Perry Local Educators Association, 460 U.S. 37, 45-46 (1983).

Virginia v. Black, 538 U.S. 343, 347-348 (2003).

Wayfield v. Town of Tisbury, 925 F. Supp. 880, 885 (D. Mass 1996).

Wisconsin Statutes $\$ 944.21(8)$.

Wisconsin Statutes § 948.11(4). 
Copyright of Preservation, Digital Technology \& Culture is the property of De Gruyter and its content may not be copied or emailed to multiple sites or posted to a listserv without the copyright holder's express written permission. However, users may print, download, or email articles for individual use. 